\title{
PERCEIVED OF RELIGIOUS VALUE: MODEL PEMBENTUK PREFERENSI NASABAH BANK SYARIAH
}

\author{
Amina Sukma Dewi, SE, M.Sc ${ }^{1}$ \\ Fakultas Ekonomi dan Bisnis \\ Universitas Sebelas Maret \\ Email: dewiyaa@yahoo.co.id \\ Anggel Dwi Satria, $\mathrm{SE}^{2}$ \\ Fakultas Ekonomi dan Bisnis \\ Universitas Sebelas Maret
}

\begin{abstract}
This study aims to examine the influence of perceived of religious value, financial security, profitability, and attractiveness on customer preference in Islamic Bank branch Surakarta.

Sampling technique used was purposive sampling. The criterion of participants was respondents who prefer Islamic bank compared to other banks. There were 115 respondents in this resesearch. Methods of data analysis using Generalized Structured Component Analysis (GSCA).

The analysis showed that the FIT and AFIT values above $50 \%, 50$ they were $59,1 \%$ and $58,3 \%$. While the GFI values above 0.9 which was 0.996 . Overall, the research model was fit. Furthermore, analysis of the relationship between variables indicates that there were three hypotheses were supported and one hypothesis was not supported. The hypothesis was supported by the influence of perceive of religious value, profitability, and attractiveness to customers preference. The hypothesis was not supported the effect of financial security to the customer preference.
\end{abstract}

Keywords: Customer Preference, Perceive Religious Value; Financial Security, Profitability, Attractiveness

\section{ABSTRAK}

Penelitian ini bertujuan untuk menguji pengaruh religious value, financial security, profitability, dan attractiveness pada customer preference di Bank Syariah cabang Surakarta.

Teknik pengambilan sampel menggunakan purposive sampling. Kriteria sampel adalah responden yang lebih memilih Bank syariah dari pada bank lain.

\footnotetext{
${ }^{1}$ Dosen M anajemen Fakultas Ekonomi dan Bisnis Universitas Sebelas M aret, Surakarta. Email: dewiyaa@yahoo.co.id phone number: 081329200693

${ }^{2}$ M ahasiswa M anajemen Fakultas Ekonomi dan Bisnis Universitas Sebelas M aret, Surakarta. Email: anggel.satria@gmail.com phone number: 085669667422
} 
Jumlah responden pada penelitian ini sebanyak 115 . Metode analisis data menggunakan Generalized Structured Component Analysis (GSCA).

Hasil analisis menunjukkan bahwa nilai FIT dan AFIT diatas $50 \%$ yaitu $59,1 \%$ dan 58,3\%. Sedangkan nilai GFI diatas 0,9 yaitu 0,996. Secara keseluruhan, model penelitian telah memenuhi kriteria fit. Lebih lanjut, analisis hubungan antar variabel menunjukkan bahwa tiga hipotesis terdukung dan satu hipotesis tidak terdukung. Hipotesis yang terdukung yaitu pengaruh perceive of religious value, profitability, and attractiveness pada customers preference. Hipotesis yang tidak terdukung yaitu pengaruh financial security pada customer preference.

Kata Kunci: Customer Preference, Perceive Religious Value; Financial Security, Profitability, Attractiveness

Sebelum tahun 1970, perbankan syariah hampir tidak dikenal. Namun, pada awal tahun abad kedua puluh, perbankan Islam telah menjadi kenyataan yang tidak dapat diabaikan. Prinsip-prinsip yang mendasari perbankan syariah adalah saling menanggung risiko (mutual risk) dan bagi hasil (sharing profit) untuk semua jenis transaksi dalam aktivitas bisnis. Perbankan syariah tidak memungkinkan transaksi berdasarkan bunga (riba), perjudian (maysir), dan perdagangan spekulatif (gharar) di semua jenis pembiayaan (Raza, 2012).

Pada tahun 1991 Bank Muamalat Indonesia (BMI) sebagai bank syariah pertama yang digunakan sebagai alternatif penyedia jasa keuangan/perbankan yang sesuai dengan prinsip syariah. Pendirian tersebut diprakarsai oleh Dewan Ulama Indonesia, Ikatan Cendekiawan Muslim Indonesia (ICMI) dan komunitas bisnis muslim dengan dukungan dari Pemerintah Republik Indonesia. Pendirian itupun diperkuat dengan ditetapkannya UU No. 7 tahun 1992 tentang Perbankan yang telah dirubah dalam UU No. 10 tahun 1998, UU No. 23 tahun 1999 dan UU No. 9 tahun 2004 tentang Bank Indonesia.
Perbankan syariah sendiri memiliki catatan perkembangan yang cukup membanggakan baik di luar negeri maupun di Indonesia. Pada akhir tahun 2004, ukuran industri perbankan syariah mencapai nilai miliar dan total akun perbankan syariah di seluruh dunia hampir USD \$500 miliar dan tumbuh pada tingkat rata-rata 10 - 15\%. Pertumbuhan perbankan syariah di beberapa negara mengalami peningkatan dari tahun ke tahun. Tercatat prosentase pertumbuhan perbankan syariah di lima negara yang mayoritas penduduknya adalah beragama Islam. Mulai dari tahun 2002 sampai 2006 yaitu Turki 44\%, Indonesia 60\%, Kuwait 29\%, Malaysia 20\%, dan Q atar 40\% (lihat: Bank Sentral dalam Riawan, 2009).

$\begin{array}{crr}\text { Di } & \text { Indonesia } & \text { perkembangan } \\ \text { perbankan } & \text { syariah } & \text { mengalami }\end{array}$ pertumbuhan yang baik. Hal ini dapat dilihat pada tabel 1 . 
Tabel 1. Pertumbuhan Usaha Syariah di Indonesia

\begin{tabular}{|c|c|c|c|c|c|c|c|c|}
\hline $\begin{array}{c}\text { Indikas } \\
\mathbf{i}\end{array}$ & $\begin{array}{c}1998 \\
\text { KP/UU } \\
\text { S }\end{array}$ & $\begin{array}{c}2003 \\
\text { KP/UU } \\
\text { S }\end{array}$ & $\begin{array}{c}2004 \\
\text { KP/UU } \\
S\end{array}$ & $\begin{array}{c}2005 \\
\text { KP/UU } \\
\text { S }\end{array}$ & $\begin{array}{c}2006 \\
\text { KP/UU } \\
\text { S }\end{array}$ & $\begin{array}{c}2007 \\
\text { KP/UU } \\
\text { S }\end{array}$ & $\begin{array}{c}2008 \\
\text { KP/UU } \\
\text { S }\end{array}$ & $\begin{array}{c}2009 \\
\text { KP/UU } \\
\text { S }\end{array}$ \\
\hline BUS & 1 & 2 & 3 & 3 & 3 & 3 & 5 & 6 \\
\hline UUS & - & 8 & 15 & 19 & 20 & 25 & 27 & 25 \\
\hline BPRS & 76 & 84 & 88 & 92 & 105 & 114 & 131 & 139 \\
\hline
\end{tabular}

Sumber: BI, statistik Perbankan Syariah, 2009 (dalam E-Syariah, 2010)

Tabel 1 menunjukkan bahwa secara kuantitas pencapaian perbankan syariah terus mengalami peningkatan dalam jumlah bank di Indonesia setidaknya dari awal pendirian hingga tahun 2009. Saat pertama kali berdirinya bank syariah hanya ada satu Bank Umum Syariah (BUS) dan 76 Bank Perkreditan Rakyat Syariah (BPRS). Terjadi peningkatan yang cukup baik secara kuantitas sampai pada tahun 2009 yaitu menjadi 6 Bank Umum Syariah (BUS) dan 25 Unit Usaha Syariah (UUS). Serta, jumlah Bank Perkreditan Rakyat Syariah (BPRS) mencapai 139 unit.

Selain perkembangan secara kuantitas, perkembangan asset perbankan syariah menunjukkan pertumbuhan yang baik. Data Bank Indonesia (BI) tercatat aset perbankan syariah per Oktober 2013 meningkat menjadi Rp229,5 triliun. Bila ditotal dengan aset Bank Perkreditan Rakyat Syariah (BPRS), maka aset perbankan syariah mencapai Rp 235,1 triliun (lihat www.kemenkeu.go.id).

Pemerintah dan kalangan perbankan syariah yang tengah berusaha keras mengejar pangsa pasar (market share) $5 \%$ dari kue bisnis perbankan nasional sesegera mungkin ${ }^{3}$. Bank syariah berusaha untuk mencari pelanggan sebanyak mungkin untuk bersaing dengan bank konvensional yang menggunakan suku bunga sebagai prinsip dasar. Oleh karena itu, perbankan Islam mengeluarkan berbagai produk yang dapat digunakan sebagai pengganti terbaik dari produk

\footnotetext{
${ }^{3}$ Bahtiarhs.2012. Mendorong Pertumbuhan Perbankan Syariah dengan Kembali Kepada Jati Diri. Dimuat di Kompas. Edisi Desember 2012.
}

yang ditawarkan oleh bank konvensional (Raza, 2012).

Beberapa hasil penelitian terdahulu, Idris et al., (2011) telah menjelaskan bahwa nilai-nilai agama, layanan ATM, keamanan finansial, biaya, manfaat, dan daya tarik adalah faktor-faktor yang mempengaruhi konsumen lebih memilih bank syariah. Sementara itu, Doraisamy (2011) telah menjelaskan bahwa kesadaran, profitabilitas, dan kualitas pelayanan berpengaruh signifikan terhadap preferensi konsumen dalam memilih perbankan syariah.

Nilai religius adalah variabel independen pertama dalam penelitian ini. Nilai agama adalah persepsi seseorang jika nilai-nilai agama diterapkan di bank syariah (Haque, 2009). Beberapa studi sebelumnya telah menunjukkan korelasi positif antara nilai-nilai agama dengan preferensi pelanggan perbankan syariah. Persepsi yang lebih tinggi terhadap nilainilai agama yang dianut oleh bank akan menjadi preferensi yang lebih tinggi untuk memilih transaksi di bank tersebut (Haque, 2009 dan Id ris et al., 2011).

Daya tarik mengacu pada kualitas yang menyebabkan minat atau keinginan pada sesuatu (lihat wikipedia). Daya tarik yang dimiliki oleh bank diharapkan memiliki pengaruh terhadap preferensi pelanggan untuk memilih perbankan Islam. Penelitian sebelumnya telah menunjukkan hubungan positif antara daya tarik dan preferensi pelanggan terhadap perbankan syariah (Idris et al., 2011). Selain itu, daya tarik adalah variabel independen kedua dalam penelitian ini. 


\begin{abstract}
Keamanan finansial adalah keyakinan pelanggan jika perbankan Syariah dapat menjaga keamanan uang yang disimpan (Zeithaml, 2000 dan Anderson, 1994). Penelitian sebelumnya telah menunjukkan hubungan positif antara keamanan dan preferensi pelanggan keuangan untuk memilih perbankan Islam (Idris et al., 2011). Dalam penelitian ini, keamanan finansial menjadi variabel independen ketiga. Terakhir variabel bebas dalam penelitian ini adalah profitabilitas. Profitabilitas adalah
\end{abstract} pertimbangan manfaat yang bisa diperoleh oleh konsumen ketika bertransaksi di bank syariah. Penelitian sebelumnya telah menjelaskan hubungan positif antara profitabilitas dengan preferensi konsumen perbankan syariah (Doraisamy, 2011).

Pembentukan perbankan syariah di Indonesia dapat dikatakan terlambat jika dibandingkan dengan negara lain seperti Malaysia, Iran, Pakistan dan negara-negara muslim lainnya, pasalnya populasi muslim Indonesia menempati posisi pertama (Akbar et al., 2013). Penilaian Global Islamic Financial Report (GIFR) periode 2011, Indonesia berada di peringkat ke empat yang memiliki potensi dan kondusif bagi perkembangan industri keuangan Islam setelah Iran, Malaysia dan Arab Saudi (Alam, 2012).

Jurnal utama penelitian ini menggunakan setting penelitian yang sama yaitu bank syariah. Realitas saat ini di Indonesia sebagai negara muslim terbesar di dunia, namun masih kalah bersaing dengan negara lain dalam pengembangan perbankan syariah, sehing ga penulis ingin menguji apakah ada kesamaan alas an nasabah negara mayoritas muslim lain dengan nasabah di Indonesia untuk lebih memilih bank syariah dibandingkan dengan bank lain.

Studi ini bertujuan untuk mengetahui efek religious value dalam mempengaruhi nasabah memilih transaksi di perbankan syariah. Walaupun kemudian, secara umum peneliti juga menguji faktor-faktor lain dalam mempengaruhi nasabah memilih perbankan syariah. Studi terdahulu menunjukkan berbagai variabel digunakan untuk membangun model dan pengaturan penelitian yang dapat mempengaruhi preferensi konsumen dalam memilih transaksi di bank syariah (Haque et al., 2009; Idris et al., 2011; Doraisamy, 2011; Raza, 2012).

Hasil studi sebelumnya pada model yang berbeda dapat menjelaskan fenomena yang telah dilakukan. Fenomena ini menyebabkan kesulitan ketika model diterapkan untuk pengaturan yang berbeda. Kondisi ini memberikan kesempatan untuk membangun model alternatif yang sesuai dengan kondisi nyata. Penulis memilih nasabah bank syariah di Surakarta sebagai pengaturan untuk diamati karena merupakan kondisi riil preferensi konsumen dalam memilih transaksi di perbankan syariah.

Ada lima variabel dalam membangun model penelitian ini. Preferensi nasabah bank syariah sebagai variabel dependen. Sementara, persepsi nilai-nilai agama, daya tarik, keamanan finansial, dan profitabilitas adalah variable independen yang digunakan untuk membangun model penelitian ini.

\section{TELAAH PUSTAKA}

\section{Preferensi Nasabah pada Bank Syariah}

Preferensi pelanggan adalah persepsi dan kepuasan pelanggan terhadap transaksi di perbankan syariah (Haque, 2009). Doraisamy (2011) mendefinisikan preferensi pelanggan adalah alasan pelanggan untuk memilih produk dan layanan perbankan syariah.

Penelitian sebelumnya menjelaskan preferensi konsumen perbankan syariah dipengaruhi oleh variabel independen seperti religious value, attractiveness, 
financial security, dan profitability (lihat Doraisamy, 2009; Haque, 2011; Idris et al., 2011). Fenomena ini menunjukkan jika variabel independen dapat membangun preferensi pelanggan perbankan syariah. Selain itu, hasil ini memberikan konsep bagi pemasar, untuk meningkatkan preferensi konsumen perbankan syariah.

\section{Perceived of Religious value}

Nilai keagamaan berperan penting bagi seseorang untuk memilih bank syariah. Nilai keagamaan merupakan persepsi seseorang apabila nilai-nilai agama diterapkan di bank syariah. Persepsi yang lebih tinggi terhadap nilai agama yang dianut oleh bank akan menjadi preferensi yang lebih tinggi untuk memilih transaksi di bank tersebut (Haque et al., 2009). Adapun nilai keagamaan dapat dilihat dari kebijakan-kebijakan yang dijalankan oleh bank dan pengoperasiannya tidak melanggar syariat agama.

Beberapa penelitian sebelumnya menunjukkan korelasi positif antara nilainilai agama dengan preferensi pelanggan perbankan syariah (Idris et al., 2011). Begitu pula penelitian yang dilakukan Haque et al., (2009) yang menjelaskan bahwa faktor nilai agama dan kepercayaan berpengaruh pada persepsi seseorang terhadap bank syariah. Hal serupa diungkapkan dalam penelitian Ahmad dan Haron (2002) yang menjelaskan tentang sikap konsumen di Malaysia dan menemukan bahwa 55\% dari responden menerapkan nilai keagamaan sebagai alasan utama dalam memilih bank syariah. Dengan demikian dapat ditarik hipotesis:

H1 : Perceived of religious value berpengaruh pada preferensi nasabah dalam memilih bank syariah

\section{Financial Security}

Selain faktor nilai keagamaan,
keamanan finansial juga menjadi
pertimbangan dalam memilih bank syariah. Keamanan finansial merupakan keyakinan seseorang sebagai nasabah terhadap bank syariah bahwa bank syariah mampu menjaga keamanan uang yang disimpan (Zeithaml, 2000 dan Anderson, 1994).

Penelitian yang dilakukan Idris et al., (2011) menjelaskan bahwa keamanan finansial merupakan faktor penting bagi nasabah untuk memilih bank syariah. Keamanan finansial dalam hal ini dapat ditunjukkan dengan adanya kemudahan dan keamanan dalam transaksi, tersedianya ATM, investasi tanpa resiko, dan kondisi keuangan yang stabil. Penelitian Zeithaml (2000) dan Anderson (1994) menjelaskan terdapat hubungan yang signifikan antara kepuasan konsumen dengan kinerja keuangan.

Seorang nasabah akan merasa puas pada bank syariah yang dipilihnya apabila bank syariah tersebut dapat memberikan keamanan finansial seperti yang diharapkan. Dari uraian di atas dapat ditarik hipotesis:

\section{H2 : Financial security berpengaruh pada preferensi nasabah dalam memilih bank syariah.}

\section{Profitability}

Profitabilitas merupakan faktor penting bagi seseorang untuk memilih jasa keuangan atau perbankan. Profitabilitas sendiri didefinisikan sebagai tingkat ratarata antara keuntungan dan bagi hasil (Metawa dan Almossawi (1998) dalam Doraesamy et al., (2011).

Penelitian yang dilakukan oleh Doraesamy et al., (2011) menjelaskan bahwa seorang nasabah akan menggunakan produk bank syariah dengan melihat tingkat profitabilitasnya. $\mathrm{Hal}$ ini diperkuat dengan penelitian Idris et al., (2011) yang menyatakan bahwa faktor profitabilitas atau tingkat bagi hasil menjadi faktor dominan seseorang dalam memilih atau bertransaksi di perbankan syariah. Lebih lanjut, maka: 


\section{H3 : Profitability berpengaruh pada preferensi nasabah dalam memilih bank syariah.}

\section{Attractiveness}

Attractiveness atau daya tarik merupakan minat atau keinginan pada sesuatu (wikipedia). Kemampuan yang dimiliki oleh bank syariah menjadi daya tarik tersendiri bagi nasabahnya. Penelitian yang dilakukan oleh Idris (2011) menunjukkan bahwa terdapat hubungan yang positif antara daya tarik dan preferensi pelanggan terhadap perbankan syariah. Daya tarik yang dimiliki bank lebih mengarah pada keadaan fisik dan pelayanan dari bank syarih tersebut, seperti tempat yang bersih dan nyaman, pelayanan yang bagus dan ramah, sehingga membuat nasabah merasa tertarik untuk memilih bank syariah tersebut. Dari uraian di atas dapat ditarik kesimpulan :

\section{H4 : Attractiveness berpengaruh pada preferensi nasabah dalam memilih bank syariah.}

\section{METODE PENELITIAN}

Pengumpulan data untuk pengujian hipotesis yang dikonstruksikan menggunakan kuesioner. Oleh karena itu, data penelitian ini termasuk ketegori data primer. Populasi dalam penelitian ini adalah nasabah yang menabung di bank syariah khususnya Surakarta, serta lebih memilih meng gunakan produk dan layanan bank tersebut. Data dikumpulkan dengan menggunakan metode purposive sampling.

Terdapat 115 responden dalam penelitian ini. Alat analisis data penelitian ini menggunakan aplikasi Generalized Structured Component Analysis (GSCA). Alat analisis GSCA melibatkan model struktural dan pengukuran secara terintegrasi. Beberapa pemeriksaan goodness of fit model overall disertai nilai cut off diberikan pada tabel berikut:

Tabel 2. Goodness of Fit Overall Model Pada GSCA

\begin{tabular}{cc}
\hline Goodness of fit & $\begin{array}{c}\text { Cut- } \\
\text { off }\end{array}$ \\
\hline SRMR & $\leq 0.08$ \\
GFI & $\geq 0.09$ \\
\hline
\end{tabular}

Tabel 3. Kriteria SRMR

\begin{tabular}{cc}
\hline SRMR & Cut-off \\
\hline$<0.05$ & Close fit (model sangat sesuai) \\
$0.05-0.08$ & Good fit (model sesuai) \\
$0.08-0.1$ & Marginal fit (model cukup sesuai) \\
$>0.1$ & Poor fit (model tidak sesuai) \\
\hline \multicolumn{2}{c}{ Sumber: Solimun, 2012 }
\end{tabular}

\section{Pengujian Instrumen Penelitian}

Kuesioner sebagai instrumen penelitian diadopsi dari penelitian terdahulu (Haque et al., 2009; Idris et al., 2011; Doraisamy, 2011; Raza, 2012) yang disesuaikan dengan kondisi setting penelitian. Uji instrumen meliputi uji validitas yang dilakukan untuk memastikan bahwa item pernyataan kuesioner mengukur variabel yang seharusnya diukur, dan uji reliabilitas untuk menguji konsistensi item pernyataan. Pengujian 
dilakukan dengan confirmatory factor cronbach apha untuk uji reliabilitas. Hasil analysis (CFA) untuk uji validitas dan pengujian terlihat di tabel 4.

Tabel 4. Uji Validitas

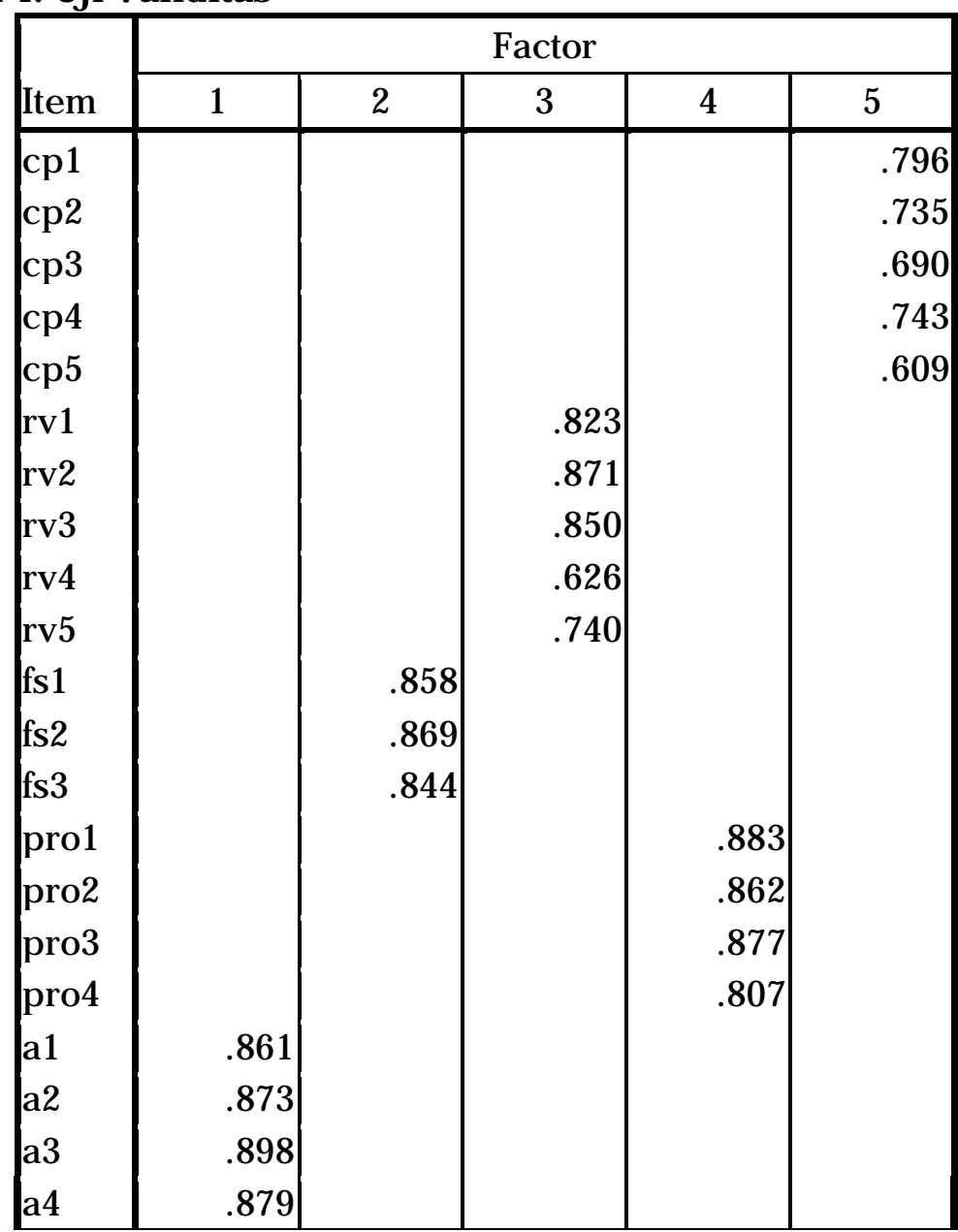

Keterangan:

$\mathrm{cp}:$ : customer preference;

Prv : perceive religious value;

fs : financial security;

pro : probability;

a : attractiveness

Tabel 4 mengindikasi bahwa item pernyataan kuesioner studi ini valid berdasarkan nilai loading factor diatas 0,5. Setiap item mengukur variabel yang seharusnya diukur berdasarkan pengkelompokkan loading factor item pada kolom factor. Hasil tersebut juga menunjukkan semua item terestrak secara sempurna.

Uji reliabilitas dilakukan setelah uji validitas lolos. Berikut adalah hasil uji reliabilitas (tabel 5). 
Tabel 5. Uji Reliabilitas

\begin{tabular}{lc}
\hline Variabel & Cronbach Alpha \\
\hline Customer preference & 0,804 \\
Perceived religious value & 0,849 \\
Financial security & 0,908 \\
Probability & 0,936 \\
Attractiveness & 0,920 \\
\hline
\end{tabular}

Hasil uji reliabilitas pada tabel 5 mengindikasikan bahwa instrumen penelitian lolos uji reliabilitas. Hal ini ditandai dengan skor cronbach alpha diatas 0,6.

\section{Measures of Fit Model}

Tabel 6. Measures of Fit Model

\begin{tabular}{lc}
\hline Indikator & Skor \\
\hline FIT & 0.591 \\
AFIT & 0.583 \\
GFI & 0.996 \\
SRMR & 0.123 \\
NPAR & 46 \\
\hline
\end{tabular}

Skor FIT dan AFIT berturut-turut $59,1 \%$ dan $58,3 \%$ mengindikasi bahwa variabel perceived religious value, financial security, probability, attractiveness dan customer preference mampu menjelaskan model 58,3\% sedangkan $41,7 \%$ dijelaskan oleh variabel yang tidak diamati dalam studi ini. GFI 0,996 diatas cut-off yang disyaratakan yakni 0,900 , skor ini menunjukkan bahwa model yang diteliti memiliki level fit yang tinggi, artinya model fit. Sedangkan nilai
Analisis SEM-GSCA mensyaratkan bahwa model yang dikonstruksi fit bila memenuhi salah satu unsur dari GFI atau SRMR. Sedangkan nilai FIT dan AFIT dalam GSCA sepadan dengan nilai $R^{2}$ dan adjusted $R^{2}$ dalam analisis regresi. Tabel 6 merupakan hasil measures of fit model studi ini.

SRMR yang disyaratkan sebesar kurang dari atau sama dengan 0,08 tidak terpenuhi. Namun, model dalam studi ini tetap dikategorikan fit (www.SEMGeSCA.org).

\section{HASI L DAN PEMBAHASAN}

\section{Profile Responden}

Partisipan studi ini adalah nasabah bank syariah di Surakarta. Detail responden ditampilkan di tabel 7 . 
Tabel 7. Deskripsi Statistik

\begin{tabular}{lc}
\hline \multicolumn{1}{c}{ Item } & Total \\
\hline Jenis Kelamin & \\
Pria & 57 \\
Wanita & 58 \\
\hline Usia & \\
$20-30$ & 55 \\
$31-40$ & 46 \\
$41-50$ & 7 \\
$>50$ & 7 \\
\hline Pendidikan Terakhir & \\
SMA & 55 \\
Diploma & 4 \\
S1 & 50 \\
S2 & 6 \\
\hline Pekejaan & \\
Pelajar & 45 \\
Pegawai & 60 \\
Pengusaha & 7 \\
Lainnya & 3 \\
\hline Penghasilan per Bulan & \\
1 - 2.5 juta & 50 \\
2.5 - 4 juta & 49 \\
$4-5.5$ juta & 11 \\
> 5.5 juta & 5 \\
\hline
\end{tabular}

Sumber: Data Primer yang Diolah, 2014

Tabel 7 menunjukkan statistik deskriptif komposisi responden; terdiri dari $57 \%$ laki-laki dan 58\% wanita. Data tersebut menunjukkan bank syariah di Surakarta memiliki nasabah yang relatif sama secara kuantitas berdasarkan gender. Berdasarkan usia responden, terdiri dari $55 \%$ berusia $20-30$ tahun; $46 \%$ berusia $31-40$ tahun, $7 \%$ berusia $41-50$ tahun, dan $7 \%$ berusia lebih dari 50 tahun. Berdasarkan komposisi pendidikan responden terdiri dari 55\% adalah SMA; 4\% adalah diploma; $50 \%$ adalah $\mathrm{S} 1$; dan $6 \%$ adalah S2. Aspek pekerjaan responden terdiri dari $45 \%$ adalah pelajar; $60 \%$ adalah pegawai; $7 \%$ adalah pengusaha; dan $3 \%$ adalah pekerjaan lain. Statistik deskriptif juga melaporkan tentang pendapatan tingkat per bulan terdiri dari $50 \%$ berada diantara 1.000 .000
- 2.500.000; 49\% adalah 2.500.000 $4.000 .000 ; 11 \%$ adalah 4000000 5.500.000; dan 5\% leb ih dari 5,5 juta.

Penyajian data deskriptif tersebut memberikan wawasan kepada bank syariah khususnya di Surakarta untuk mengimplementasikan penemuan dalam penelitian ini sesuai dengan latar belakang nasabah. Data ini penting karena pengaturan penelitian yang berbeda memungkinkan mendapati hasil yang berbeda pula. Oleh karena itu, bank syariah khususnya di Surakarta disarankan untuk melihat kondisi latar belakang nasabah dan pengaturan.

Berdasarkan analisis SEM-GSCA, terdapat tiga hipotesis yang didukung dan satu hipotesis yang ditolak. Tabel 5 dan gambar 1 merupakan hasil analisis pengujian hipotesis. 


\section{Tabel 8. Path Coefficients}

\begin{tabular}{llll}
\hline Hubungan Variabel & Estimastes & SE & CR \\
\hline rv- $>$ cp & 0.348 & 0.076 & $4.57^{*}$ \\
fs- $>$ cp & -0.145 & 0.062 & $2.35^{*}$ \\
pro- $>c p$ & 0.161 & 0.074 & $2.16^{*}$ \\
a- $>c p$ & 0.342 & 0.105 & $3.25^{*}$ \\
\hline \multicolumn{4}{c}{$C^{*}=$ significant at .05 level }
\end{tabular}

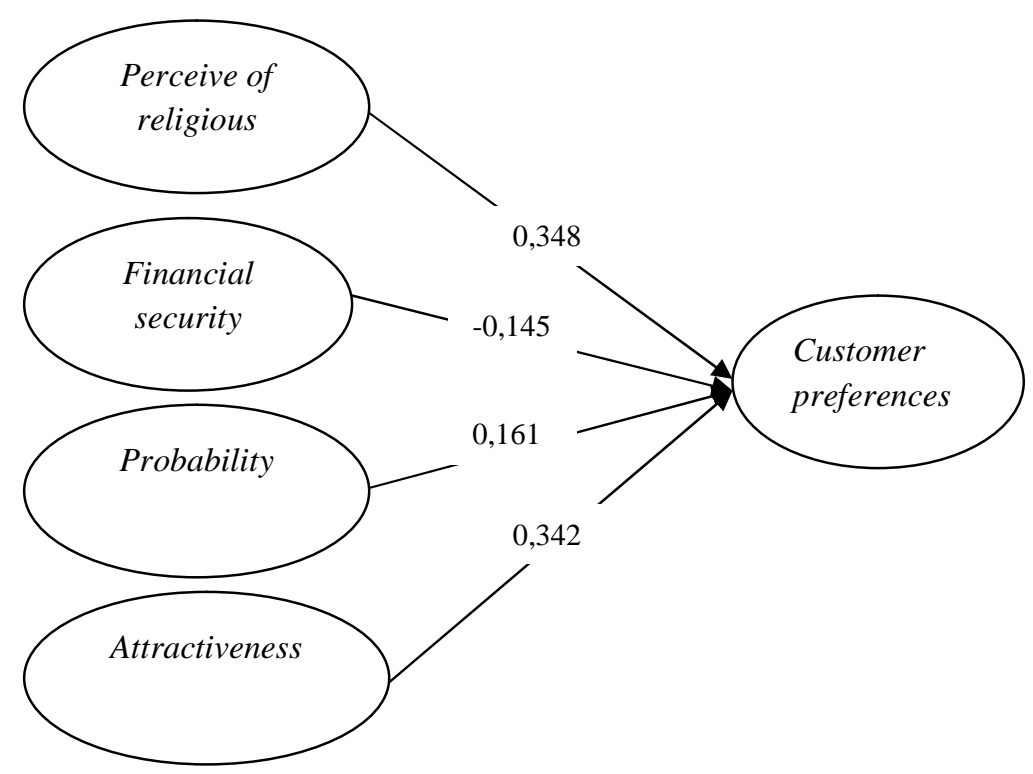

Gambar 1: Model Penelitian

Pengujian hipotesis berdasarkan derajad signifikansi $5 \%$ dengan nilai CR lebih dari atau sama dengan 1,96. Hasil tabel 8 dan gambar 1 mengindikasikan bahwa hanya hipotesis 2 tidak didukung. Hipotesis 2 yang menyatakan bahwa financial security berpengaruh terhadap customer preference, tidak didukung karena nilai CR sebesar 2,35 diatas 1,96 pada level signifikansi $5 \%$, namun nilai hubungan bersifat negatif yakni -0,145.

Sedangkan hipotesis lainnya didukung. Hipotesis 1 yang menyatakan bahwa perceived of religious berpengaruh terhadap customer preference, didukung. Nilai CR sebesar 4,57 diatas cut off level
$1 \%$, yakni 2,56. Hasil ini menunjukkan adanya hubungan positif dari nilai religius terhadap preferensi pelanggan. Hasil penelitian ini mengindikasikan persepsi nilai agama menjadi variabel yang berpengaruh pada nasabah untuk lebih memilih menyimpan uang mereka di bank syariah cabang Surakarta.

Hipotesis berikutnya, yakni hipotesis 3 menyatakan bahwa probability berpengaruh terhadap customer preference, didukung. Berdasarkan skor CR sebesar 2,16 diatas rule of thumb sebesar 1,96 pada level signifikansi $5 \%$. Artinya, jika profitabilitas yang tinggi diberikan kepada nasabah dapat membuat 
semakin kuat preferensi nasabah untuk menabung di bank syariah.

Terakhir, hipotesis tentang pengaruh attractiveness terhadap customer preference yang merupakan hipotesis 4 didukung. Skor $C R$ sebesar 3,25 diatas 2,56 pada level signifikansi $1 \%$. Hasil ini membuktikan bahwa jika daya tarik yang lebih tinggi dari bank syariah maka akan membentuk preferensi nasabah terhadap bank tersebut.

\section{PEMBAHASAN}

Hasil penelitian ini mengungkapkan bahwa persepsi nilai agama pada bank menjadi variabel yang paling baik dalam mempengaruhi nasabah untuk memilih bank syariah dibandingkan bank lain. Hal ini berarti jika bank syariah ingin menjaga dan mengembangkan jumlah nasabah, maka sebaiknya bank syariah harus memastikan semua kegiatan bank berdasarkan Prinsip Islam.

Secara teoritis, penelitian ini juga mendukung penelitian sebelumnya yang menjelaskan bahwa jika lebih tinggi dirasakan persepsi nilai agama pada bank syariah maka semakin tinggi pula preferensi nasabah terhadap bank terseb ut (Idris et al., 2011).

Sementara itu, hasil penelitian selanjutnya menjelaskan bahwa keamanan finansial tidak berpengaruh terhadap preferensi nasabah terhadap bank syariah. Hal ini mununjukkan bahwa keamanan finansial diindikasikan bukan sebagai alasan bagi nasabah untuk memilih bank syariah. Secara teoritis, penelitian ini juga tidak mendukung penelitian sebelumnya yang menjelaskan bahwa keamanan finansial yang lebih tinggi membentuk preferensi nasabah yang lebih tinggi seperti yang disimpulkan oleh Raza (2012).

$\mathrm{Hal}$ ini mungkin disebabkan persepsi nasabah jika uang mereka yang disimpan di perbankan syariah ataupun konvensional sudah pasti akan mendapatkan asuransi. Dengan demikian keamanan finansial di perbankan syariah tidak membuat nasabah untuk memilih bank syariah dibandingkan bank konvensional.

Hipotesis selanjutnya menyatakan bahwa profitabilitas berpengaruh positif pada preferensi nasabah. Secara teoritis, penelitian ini juga mendukung penelitian sebelumnya yang menjelaskan profitabilitas yang tinggi membuat preferensi nasabah yang tinggi pula (Doraisamy et al., 2011).

Ini menunjukkan bahwa nasabah menyukai tingkat keuntungan dan sistem pembagian risiko yang diterapkan pada bank syariah di Surakarta. Oleh karena itu, bank syariah dapat meningkatkan sistem ini untuk mengembangkan jumlah nasabah.

Terakhir, hasil yang diperoleh dari penelitian ini mendukung hipotesis yang menyatakan bahwa daya tarik berpengaruh positif pada preferensi nasabah. Hal ini ditunjukkan dengan nilai positif hubungan dan nilai signifikansi daya tarik perbankan syariah. Secara teoritis, penelitian ini juga mendukung penelitian sebelumnya yang menjelaskan daya tarik yang lebih tinggi akan membuat preferensi nasabah yang lebih tinggi pula (Idris et al., 2011).

Hal ini menunjukkan kenyamanan merupakan daya tarik tersendiri bagi nasabah perbankan syariah khususnya di Surakarta. Oleh karena itu, meningkatkan kenyamanan bagi nasabah menjadi strategi yang penting untuk memperkuat preferensi nasabah.

\section{SIMPULAN}

Berdasarkan hasil pengujian penelitian ini, dapat disimpulkan bahwa preferensi nasabah pada bank syariah di Surakarta dipengaruhi oleh nilai agama yang dirasakan yang diterapkan oleh bank. Faktor nilai agama yang diterapkan 
oleh bank syariah juga menjadi pembentuk preferensi yang paling kuat pada nasabah. Daya tarik bank syariah juga berpengaruh signifikan dalam memperkuat preferensi pelanggan pada bank syariah. Selain itu, hasil penelitian ini juga menunjukkan bahwa profitabilitas menjadi faktor yang signifikan dalam mempengaruhi nasabah untuk memilih bank syariah khususnya di Surakarta.

Sementara itu, keamanan keuangan bank syariah tidak berpengaruh secara signifikan pada preferensi nasabah. Oleh karena itu, berdasarkan hasil penelitian ini, keamanan finansial tidak menjadi alasan nasabah untuk memilih pada bank syariah dibandingkan bank lain khususnya di Surakarta.

\section{Implikasi}

Penelitian ini diharapkan dapat memberikan implikasi yang dibagi menjadi dua aspek, yaitu aspek implikasi manajerial pada praktis dan penelitian selanjutnya. Studi ini memberikan wawasan pada praktisi pemasar tentang upaya yang dapat dilakukan untuk meningkatkan preferensi nasabah bank syariah. Upaya ini dapat dilakukan dengan program pemasaran seperti meningkatkan nilai-nilai agama yang dirasakan nasabah pada bank syariah. Mengingat faktor ini menjadi pembentuk preferensi terkuat pada nasabah. Strategi ini dapat dilakukan dengan upaya bank syariah untuk melaksanakan kegiatan selalu didasarkan pada prinsip-prinsip Islam.

Faktor kenyamanan dan kebersihan pada bank syariah menjadi daya tarik tersendiri bagi nasabah. Upaya meningkatkan kenyamanan nasabah dalam menggunakan produk-produk perbankan syariah, menjadi strategi yang harus ditingkatkan oleh pemasar. Sehingga bank syariah dapat bersaing dengan bank-bank konvesional. Hal yang sama pula meningkatkan profitabilitas bagi nasabah meruapakan strategi yang dapat memperkuat preferensi nasabah bank syariah.

Ruang lingkup penelitian ini difokuskan pada pengaturan bank syariah di Surakarta. Sampel dalam penelitian ini adalah nasabah bank syariah di Surakarta yang lebih memilih untuk menabung di bank tersebut dibandingkan bank-bank lainnya. Sehingga berdampak pada pembatasan model generalisasi. Oleh karena itu, kondisi ini memberikan kesempatan untuk studi selanjutnya, terutama dalam mengembangkan model pada konteks yang berbeda atau yang lebih luas.

\section{Keterbatasan Penelitian}

Penelitian ini difokuskan pada objek pengamatan bank syariah khususnya di Surakarta. Oleh karena itu, kondisi ini berdampak pada keterbatasan dalam model generalisasi. Oleh karena itu, untuk menerapkan penelitian ini dalam konteks yang berbeda, peneliti perlu memahami karakteristik produk yang melekat pada studi objek. Hal ini diperlukan agar hasil pengujian tidak bias yang dapat mempengaruhi kesalahan dalam memahami implikasi dari penelitian.

Meskipun ada keterbatasan dalam penelitian ini yang menyebabkan ketidakmampuan model untuk menggeneralisasi semua situasi, tetapi dengan prosedur pengujian terstruktur diharapkan dapat memberikan wawasan yang dapat dipercaya dalam memprediksi akurasi model preferensi pelanggan.

\section{DAFTAR PUSTAKA}

Abduh, M. and M.A. Omar. 2010. Who Patronizes Islamic Bank in Indonesia. Australian J. Islamic Law, Management And Finance, 1(1): 48-63.

Akbar, Harviz and H.D.H Ritonga. 2013. Perception of China Ethnic for 
Islamic Bank in Medan. Journal of economic and finance, Vol. 1 , No.2.

Alamsyah, Halim. 2012. Development and Prospect of Indonesian Islamic Banking Outlook: Challenges In Toward AEC 2015. Association of Islamic Economics (IAEI)

Bahtiarhs. 2012. Mendorong Pertumbuhan Perbankan Syariah dengan Kembali Kepada Jati Diri. Dimuat di Media Cetak Kompas. Edisi Desember 2012.

Cronin, J.J. Jr and Taylor, S.A. (1992), Measuring service quality: a reexamination and extension. Journal of Marketing, $\mathrm{Vol}$. 56, pp. 55-68

Doraisamy, Barathy et al. 2011. A Study on Customers' Preferences of Islamic Banking Products and Services in Sungai Petani. Academic Research International. ISSN:22239553.Volume 1 ,issue 3 , November 2011

Gronroos, C., 1982. Strategic Management and Marketing in the Service Sector. Swedish School of Economics and Business Administration, Helsing fors

Haque, Ahasanul et al.2009. Factor Influences Selection of Islamic Banking: A Study on Malaysian Customer Preferences. American Journal of Applied Sciences 6 (5): Science Publishing

Idris, Asma' Rashidah et al. 2011. Religious Value as the Main Influencing Factor to Customers Patronizing Islamic Bank. World Applied Sciences Journal : IDOSI Publications

Metawa, S. A. \& Almossawi, M. (1998). Banking behaviour of Islamic bank customers: perspectives and implications. International
Journal of Bank Marketing, 16,(7), 299-313.

Nafik, Muhammad H.R and Ratnasari, Ririn Tri. 2012. Measuring Islamic Compliance on The Moderating Effects of Islamic Knowledge Level and The Relationship Between Trust and Loyalty Intention. Phuket-Thailand: The 2012 International Conference on Business and Management

Raza, Ali et al. 2012. Customers' Satisfaction Towards Islamic Banking : Pakistan's Perspective. Arabian Journal of Business and Management Review (OMAN Chapter) Volume.1, No.6;january 2012

Reeves, C.A. and D.A. Bednar, 1996. Keys To Market Success-A Response and Another View. Journal of Retail Banking Services, 18(4): 33-40.

Riawan, Amin. 2009. Perbankan syariah: sebagai solusi perekonomian nasional. Jakarta: Asbisindo.

Solimun. 2012. Laboratorium Statistika FMIPA UB. Diakses di http:// fia.ub.ac.id/wpcontent/ uploads/2013/11/4-GSCA.pdf. Pada tanggal 2 Februari 2014.

Wan Ahmad, W.M., A. Ab Rahman, N.A. Ali and A. Che Seman, 2008. Religiosity and Banking Selection Criteria among Malays in Lembah Klang. Shariah J.16(2): 79-84.

www.sem-gesca.org

Zeithaml, V.A. 2000. Service Quality, profitability and the Economic Worth of customers: what we know and what we need to learn. Journal of the academy of marketing science, .28(1), 67-85. 2013. BI: Perbankan Syariah Berkembang Pesat. Diakses di www.kemenkeu.go.id. Pada tanggal 2 Februari 2014. 


\section{Lampiran Kuesioner Petunjuk Pengisian}

$\begin{array}{l:c}\text { SS }: & \text { Sangat Setuju } \\ \mathrm{S}: & \text { Setuju } \\ \mathrm{N}: & \text { Netral } \\ \text { TS }: & \text { Tidak Setuju } \\ \text { STS:Sangat Tidak Setuju }\end{array}$

1. Customer Preference

\begin{tabular}{|l|l|l|l|l|l|l|}
\hline Kode & \multicolumn{1}{|c|}{ Pernyataan } & SS & S & N & TS & STS \\
\hline CP1 & $\begin{array}{l}\text { Saya lebih senang bertransaksi } \\
\text { di bank syariah dibandingkan } \\
\text { bank konvensional }\end{array}$ & & & & & \\
\hline CP2 & $\begin{array}{l}\text { Saya lebih nyaman bertransaksi } \\
\text { di bank syariah dibandingkan } \\
\text { bank konvensional }\end{array}$ & & & & & \\
\hline CP3 & $\begin{array}{l}\text { Menurut saya Bank syariah lebih } \\
\text { baik dari bank konvensional }\end{array}$ & & & & \\
\hline CP4 & $\begin{array}{l}\text { Saya lebih puas bertransaksi di } \\
\text { bank syariah dibandingkan } \\
\text { bank konvensional }\end{array}$ & & & & & \\
\hline
\end{tabular}

2. Perceived of Religious Value

\begin{tabular}{|c|c|c|c|c|c|c|}
\hline Kode & Pernyataan & SS & $\mathbf{S}$ & $\mathbf{N}$ & TS & STS \\
\hline R1 & $\begin{array}{l}\text { Kebijakan yang } \\
\text { ditetapkan/diberlakukan di Bank } \\
\text { Syariah tidak bertentangan dengan } \\
\text { syariat Islam }\end{array}$ & & & & & \\
\hline $\mathrm{R} 2$ & $\begin{array}{l}\text { Bank syariah melakukan } \\
\text { operasionalnya sesuai dengan } \\
\text { prinsip AI Q uran. }\end{array}$ & & & & & \\
\hline R3 & $\begin{array}{l}\text { Bank syariah melakukan } \\
\text { operasionalnya sesuai dengan } \\
\text { prinsip Al Hadist. }\end{array}$ & & & & & \\
\hline R4 & $\begin{array}{l}\text { Bank syariah memfasilitasi } \\
\text { pembayaran zakat. }\end{array}$ & & & & & \\
\hline R5 & $\begin{array}{l}\text { Bank syariah tidak menawarkan } \\
\text { riba/bunga. }\end{array}$ & & & & & \\
\hline
\end{tabular}

3. Financial Security

\begin{tabular}{|l|l|c|c|c|c|c|}
\hline Kode & \multicolumn{1}{|c|}{ Pernyataan } & SS & S & N & TS & STS \\
\hline FS1 & $\begin{array}{l}\text { Investasi di bank syariah tidak } \\
\text { beresiko. }\end{array}$ & & & & & \\
\hline FS2 & Transaksi di bank syariah aman. & & & & & \\
\hline FS3 & Bank syariah dapat dipercaya. & & & & & \\
\hline
\end{tabular}


4. Attractiveness

\begin{tabular}{|l|l|l|l|l|l|l|}
\hline Kode & Pernyataan & SS & S & N & TS & STS \\
\hline A1 & Bank syariah nyaman & & & & & \\
\hline A2 & Bank syariah bersih & & & & & \\
\hline A3 & Pegawai Bank syariah ramah & & & & & \\
\hline A4 & Pegawai Bank syariah sopan & & & & & \\
\hline
\end{tabular}

5. Profitability

\begin{tabular}{|l|l|l|l|l|l|l|}
\hline Kode & \multicolumn{1}{|c|}{ Pemyataan } & SS & S & N & TS & STS \\
\hline Pro1 & $\begin{array}{l}\text { Tingkat bagi hasil bank syariah } \\
\text { menarik. }\end{array}$ & & & & & \\
\hline Pro2 & $\begin{array}{l}\text { Tingkat bagi hasil bank syariah } \\
\text { menyenangkan. }\end{array}$ & & & & & \\
\hline Pro3 & $\begin{array}{l}\text { Tingkat bagi hasil bank syariah } \\
\text { memuaskan. }\end{array}$ & & & & \\
\hline Pro4 & $\begin{array}{l}\text { Tingkat bagi hasil bank syariah } \\
\text { tinggi. }\end{array}$ & & & & \\
\hline
\end{tabular}


Jurnal Bisnis \& M anajemen

Vol. 14, N o. 2, 2014 : 35 - 50 